IZA DP No. 5716

Poisoning the Mind: Arsenic Contamination of Drinking Water Wells and Children's Educational Achievement in Rural Bangladesh

M. Niaz Asadullah

Nazmul Chaudhury

May 2011 


\title{
Poisoning the Mind: Arsenic Contamination of Drinking Water Wells and Children's Educational Achievement in Rural Bangladesh
}

\author{
M. Niaz Asadullah \\ University of Reading, \\ SKOPE, University of Oxford and IZA \\ Nazmul Chaudhury \\ World Bank \\ Discussion Paper No. 5716 \\ May 2011 \\ IZA \\ P.O. Box 7240 \\ 53072 Bonn \\ Germany \\ Phone: +49-228-3894-0 \\ Fax: +49-228-3894-180 \\ E-mail: iza@iza.org
}

Any opinions expressed here are those of the author(s) and not those of IZA. Research published in this series may include views on policy, but the institute itself takes no institutional policy positions.

The Institute for the Study of Labor (IZA) in Bonn is a local and virtual international research center and a place of communication between science, politics and business. IZA is an independent nonprofit organization supported by Deutsche Post Foundation. The center is associated with the University of Bonn and offers a stimulating research environment through its international network, workshops and conferences, data service, project support, research visits and doctoral program. IZA engages in (i) original and internationally competitive research in all fields of labor economics, (ii) development of policy concepts, and (iii) dissemination of research results and concepts to the interested public.

IZA Discussion Papers often represent preliminary work and are circulated to encourage discussion. Citation of such a paper should account for its provisional character. A revised version may be available directly from the author. 


\title{
ABSTRACT \\ Poisoning the Mind: Arsenic Contamination of Drinking Water Wells and Children's Educational Achievement in Rural Bangladesh ${ }^{*}$
}

\begin{abstract}
Bangladesh has experienced the largest mass poisoning of a population in history owing to contamination of groundwater with naturally occurring inorganic arsenic. Prolonged drinking of such water risks development of diseases and therefore has implications for children's cognitive and psychological development. This study examines the effect of arsenic contamination of tubewells, the primary source of drinking water at home, on the learning outcome of school-going children in rural Bangladesh using recent nationally representative data on secondary school children. We unambiguously find a negative and statistically significant correlation between mathematics scores and arsenic-contaminated drinking tubewells at home, net of the child's socio-economic status, parental background and school specific unobserved correlates of learning. Similar correlations are found for an alternative measure of student achievement and subjective well-being (i.e. self-reported measure of life satisfaction), of the student. We conclude by discussing the policy implication of our findings in the context of the current debate over the adverse effect of arsenic poisoning on children.
\end{abstract}

JEL Classification: I21, Z12, O12, O15

Keywords: drinking water pollution, Madrasa, subjective well-being, Bangladesh

Corresponding author:

M. Niaz Asadullah

Department of Economics

University of Reading

PO Box 218, Whiteknights

Reading, RG6 6AA

United Kingdom

E-mail: m.asadullah@reading.ac.uk

\footnotetext{
* The findings, interpretations, and conclusions expressed in this paper are entirely those of the authors. They do not necessarily represent the views of the World Bank and its affiliated organizations, or those of the Executive Directors of the World Bank or the governments they represent. We would like to thank Michelle Riboud and seminar participants at the University of Reading for valuable comments on an earlier version of the paper. We are grateful to Khawaja Minnatullah and the National Arsenic Mitigation Information Center (NAMIC), Government of Bangladesh, for helping us to access official data on arsenic contamination of water wells in our survey sites. We are also thankful to Zihad Hassan of Data Analysis and Technical Assistance (DATA) limited for research assistance. We are also indebted to Daniel Rees and two anonymous referees for their very helpful comments. The usual disclaimers apply.
} 
In the parlance of the World Health Organization, arsenic has been responsible for the largest mass poisoning of a population in history (Smith, Lingas, and Rahman, 2000). The victims are 28 to 35 million Bangladeshis who have been drinking groundwater contaminated with naturally occurring inorganic arsenic for over two decades (BGS/DPHE, 2001). Continuous drinking from arsenic-laced wells can cause various health disorders including birth complications and cancer (Waalkes et al, 2007; Li et al., 2008; Tokar et al., 2011). Low doses of arsenic, consumed over years, can ultimately cause death (Argos et al, 2010). A low-cost solution to the problem is yet to become commercially available in developing countries. Rural households do not have easy access to an affordable technology that can either remove arsenic from drinking water or at least reduce it to a level at which it has no adverse effect on human well-being. Therefore, the majority of the affected population continues to remain exposed to the crisis.

While the adverse effect of arsenicosis ${ }^{1}$ on adult health is well-documented, little is known about the effect of the poor health caused by drinking arsenic-contaminated groundwater, on skills formation. For instance, children growing up in affected households are likely to be vulnerable to poor health and hence have a poorer prospect of developing cognitive skills. Arsenic poisoning is also alleged to have created problems of exclusion for children at school and within the community and hence, has implications for their educational participation. This study aims to shed light on the potential effects of arsenicosis by examining the relationship between the arsenic contamination status of

\footnotetext{
${ }^{1}$ The term "arsenicosis" refers to the effect of arsenic poisoning, usually over a long period such as from 5 to 20 years.
} 
water wells at home, and children's school performance in rural Bangladesh. Most children are exposed to arsenic largely through fluid intake at home and in school. Therefore, we use survey data for a large sample of registered secondary school students (of grade 8) in rural Bangladesh and investigate the effects of exposure to arsenic poisoned water wells at home on test scores, net of school-level exposure and various individual and family-specific correlates of learning. Significant small-scale variability of arsenic concentrations in groundwater allows us to establish the causal effect by comparing test scores between otherwise similar children in the same school/classroom who did and did not have arsenic contaminated tubewells at home.

Individual level exposure to arsenic contaminated water at home is ascertained on the basis of self-reported data. Such data on contamination of water wells may be subject to measurement error, a concern we address by utilizing official contamination statistics on water wells for our survey sites. Comparison of the distribution of self-reported data with results of official screening exercise of water wells confirms the reliability of our self-reported measures of exposure to arsenic-contaminated water wells at home. Apart from measurement error problems associated with self-reported data, identifying the causal effect of arsenic-contaminated drinking can be difficult in the presence of nonrandom switching of households to safe water wells. Parents who care more about their children may respond to arsenic contamination either by migrating to safer neighbourhoods, or by accessing clean water from an alternative source. However, rural households have relied on the government to detect arsenic poisoning of the water well. By testing children soon after water wells at home were officially tested for the presence 
of arsenic, we are able to minimize the possibility of bias owing to non-random geographic relocation away from affected water wells.

We unambiguously find a negative, statistically significant correlation between mathematics scores and arsenic contaminated drinking tubewells at home, net of the student's socio-economic status, parental background and school specific unobserved correlates of learning. Similar correlations are found for an alternative measure of student achievement and subjective well-being (i.e. self-reported measure of life satisfaction) of the student. Once again, these correlations remain robust when controlling for schoollevel exposure to arsenic and socio-economic background of the child. The negative effect on children may arise because visible manifestations of arsenicosis lead to social ostracism at school. Alternatively, the effect may be driven by non-social channels where continuous drinking of arsenic contaminated water stunts cognitive development and/or makes children more susceptible to other diseases thereby adversely affecting their health status. We show that the negative effect is only specific to the sample of non-religious schools. This lends support to the socialization hypothesis. The effect is absent in the case of Islamic schools (i.e. madrasas) which implement strict dress codes and disciplinary rules that potentially limit scope for social ostracism based on visible signs of arsenicosis. Bangladesh, along with West Bengal (India), today constitutes the largest population in the world exposed to arsenic from drinking water. In both regions, children constitute nearly $50 \%$ of the affected population. Similar contamination of ground water with arsenic has occurred in Thailand, Nepal and Pakistan, and major problems have also been identified in some areas of China, Ghana, the USA, and South America (Misra, 
2006). Therefore, it is hoped that our findings will inform government policies in other affected regions as well.

Lastly, there is a large economics literature on the interplay between health and education (Grossman, 2008). This includes studies that explore the health effects of education (e.g. see Sun and Yao, 2010). However, a second strand of the literature examines the reverse relationship where the health status of individuals and health shocks impact school attainment (e.g. see Perri, 1984; Gomes-Neto, Hanushek, Leite and FrotaBezzera, 1997; Corman and Chaikind, 1998; Kaestner and Grossman, 2009; Ding, Lehrer, Rosenquist and Audrain-McGovern, 2009; Zhao and Glewwe, 2010). These studies measure health status in a variety of ways, by looking at for example nutrition, illnesses such as depression, obesity and birth-weight. Our study contributes to this literature by looking at the effect of an environmental determinant of health - exposure to arsenic contaminated drinking water.

The remaining part of the paper is organized as follows. Section 2 elaborates on the background to the study. Section 3 discusses the data and sampling. The main results are reported in Section 4, and Section 5 gives the conclusions of the study.

\section{$2 \quad$ Background}

\subsection{Genesis of Arsenicosis in Bangladesh}

Tubewells are the single most important source of fluid (drinking water) in Bangladesh. According to the 2001 Population Census, 88\% of rural households use tubewells as the main source of drinking water although the 1999-2000 Household Income and Expenditure Survey puts this figure at $95.7 \%$. Nevertheless, usage of tubewells is relatively a recent phenomenon. Even in the early 1970s drinking from open water bodies 
was common practice. However, surface water is often contaminated with bacteria and hence a major cause for waterborne diseases such as cholera, dysentery, typhoid, and diarrhoea. Unsurprisingly, these water-related illnesses in young children were the leading cause of mortality. Therefore, for the past three decades, the government and various international organizations have promoted shallow (tube) wells, as a course for safe drinking water from underground aquifers. Tubewell construction strongly accelerated in the 1980s. Around 11 million tubewells were installed during this period, the vast majority being in private ownership (van Geen et al., 2005). This initiative has helped control water-borne diseases, but in many areas it has had the unintended sideeffect of exposing the population to another health problem - toxic arsenic in ground water.

Pollution by arsenic occurs naturally through the dissolution of minerals and ores, and concentrations in groundwater in some areas are elevated as a result of erosion from local rocks (McArthur et al., 2001). While the World Health Organization (WHO) maximum permissible level is 10 micrograms of arsenic per litre, the Government of Bangladesh uses a much higher standard - 50 micrograms per litre as "safe". At the time of mass installation of tubewells in Bangladesh, during the 1980s, the aquifers were not tested for arsenic. Arsenic was first discovered in 1994. Realising the seriousness of the situation, a mass detection-campaign was undertaken during the late 1990s. A systematic census of tubewells in suspected areas was followed by comprehensive awareness campaigns. According to government sources, there are 271 arsenic prone sub-districts (Upazilas) in Bangladesh (BAMWSP, 2005). As part of a multi-million dollar donor financed project, 5 million of the country's 11 million tubewells were tested in arsenic- 
prone areas. 1.4 million (or roughly 29 percent) were found to be contaminated i.e. they have arsenic levels above the Bangladeshi safety standard; a total of 32 million people drink from such tubewells (Chakraborti et al., 2004).

Intake of arsenic over the permissible level over a period of several years leaves a person at risk of developing arsenic related diseases. So far, 40,000-100,000 people have already developed visible pigmentation of skin, skin lesions, swollen limbs, warts, gangrene, and cancer and/or invisible damage to lungs, kidneys, and other internal organs, as well as loss of feeling in the hands and legs (BAMWSP, 2005). Not surprisingly, arsenic toxicity has been recognised as an acute national problem by the Government of Bangladesh.

\subsection{Arsenicosis and children's development}

Prolonged exposure to inorganic arsenic can lead to hallucinations, agitation, emotional lability, memory loss, gangrene and skin as well as internal (lungs, bladder and kidneys) cancer (ATSDR, 2005). There are a number of studies documenting the adverse effects of arsenicosis on the physical wellbeing of adults. There is evidence that chronic arsenic exposure causes adverse pregnancy outcomes in terms of spontaneous abortion, still birth and pre-term birth rates (Ahmad et al., 2001; Ehrenstein et al., 2006). Smith et al. (2006) find significant increases in mortality from lung cancer and bronchiectasis in persons with probable exposure to high concentrations of arsenic in drinking water in early childhood. For various reasons, arsenic exposure is a public health concern for children and infants as well. Newborns and infants are especially susceptible as arsenic may be passed from mother to child during pregnancy or through breastfeeding. Claudia et al. (2003) find that moderate arsenic exposures from drinking water during pregnancy leads 
to a lower average birth weight. Children who are exposed to high levels of arsenic in their drinking water are seven to twelve times more likely to die of lung cancer and other lung diseases in young adulthood (Smith et al. 2006).

The existing health literature on children is however limited regarding the heterogeneity in the impact of arsenicosis. For adults, there is evidence to suggest that the symptoms of arsenicosis vary according to an individual's demographic and socioeconomic attributes. For instance, Hadi and Parveen (2004) studied the correlation between the prevalence of arsenicosis and various individual and household level factors such as age, sex, education and the economic status of the household ${ }^{2}$. They reported a negative association between economic status and the prevalence of arsenicosis. Poor people, who earn their living from physical labour, were found to drink more fluid than the non-poor. On the other hand, non-poor people are known to consume more nutritious food than poor people. Indeed there is evidence that nutritional deficiencies increase susceptibility to arsenic health effects. Using data from West Bengal, Mitra et al. (2004) investigated whether dietary nutrient intake alters the risk of arsenic-induced skin lesions, including alterations in skin pigmentation and keratoses. The authors concluded that low intake of calcium, animal protein, folate, and fiber may increase susceptibility to arseniccaused skin lesions although the magnitude of increased risks related to these dietary deficiencies is small.

The findings discussed above have obvious implications for children’s cognitive development. There are at least four reasons why educational development of children is likely to be hampered owing to arsenic contamination of drinking water wells at home.

\footnotetext{
${ }^{2}$ The authors drew upon a dataset of 1654 individuals all of whom reside in a single village in South-West Bangladesh.
} 
First, children who have continuously drunk from arsenic contaminated tubewells are likely to have poorer health status and thus under-perform in schools compared to peers who have grown up in household unaffected by arsenic. In case of early-life exposure (e.g. arsenic passed from mother to child during pregnancy or through breastfeeding), the adverse health effect can be more severe. Second, drinking of contaminated water could lead to arsenicosis among adult members at home which in turn may affect income adversely -- labour productivity of wage-earning adult members is likely to be reduced owing to declining health conditions ${ }^{3}$. Given binding credit constraints in rural areas, reduced income may have an adverse effect on children's school participation and attainment.

Third, there is an emerging body of medical evidence documenting the direct impact of arsenic exposure on the intellectual development of children. A study in Mexico by Calderon et al. (2001) found that chronic malnutrition, combined with exposure to arsenic, seriously affected verbal ability and long term memory of elementary school attending children (6-9 years of age). Arsenic concentration in urine was inversely correlated with verbal IQ, concepts factor (language), and knowledge factor (verbal comprehension and long-term memory). The negative effect of arsenicosis in verbal IQ scores remained, even after accounting for nutritional status and other confounders. More recent research on arsenicosis and cognition corroborates these findings. For example, Wasserman et al. (2004) concluded that exposure to arsenic in drinking water in Bangladesh was associated with reduced intellectual function in 10 year

\footnotetext{
${ }^{3}$ There is an economics literature on the labour market returns to physical appearance where it is often reported that average-looking people earn less than good-looking individuals (e.g. Hamermesh and Biddle, 1994). If similar effects are present in the Bangladeshi labor market, adult income may also suffer following arsenicosis even when labor productivity remains unchanged. Visible skin damages owing to arsenicosis can reduce labour market earnings.
} 
old children ${ }^{4}$. Exposure was measured in terms of both well-water and urinary arsenic. Exposure to arsenic from drinking water was associated with reduced intellectual function after adjustment for socio-demographic covariates and water Manganese (Mn). Children with arsenicosis (exposure to water arsenic at level above that prescribed by WHO) achieved significantly lower performance than did children with water arsenic levels below the WHO limit. Interestingly, the association was generally stronger for well-water arsenic than for urinary arsenic ${ }^{5}$. To be precise, water arsenic concentrations of 10 and $50 \mu \mathrm{g} / \mathrm{L}$ were associated with decrements in Full-Scale IQ raw scores of 3.8 and 6.4 points, respectively. In a follow up study using a sample of 301 randomly selected children (6 year olds), Wasserman et al. (2007) reported similar results.

Finally, there is evidence that, when exposed to arsenic at early ages, children can develop visible symptoms such as pigmentation and arsenical skin lesions by the time they reach secondary school age ${ }^{6}$. Children with keratosis may become socially ostracised at school owing to the common belief that arsenicosis is contagious. If there are positive peer effects in classroom learning, affected children will be worse-off as arsenicosis would limit social interactions at school. Anecdotal evidence suggests that children with symptoms are often not sent to school in an effort to hide the problem and hence avoid such ostracism at school (Hassan et al., 2005).

\footnotetext{
${ }^{4}$ Test instrument on intellectual function was drawn from the Wechsler Intelligence Scale for Children, version III.

${ }^{5}$ However, evidence from extant epidemiological and public health literature is not conclusive enough owing to the very small size of the sample. For example, Calderon et al. (2001) utilize a sample of 80 children where only 41 were exposed to high levels of arsenic. Similarly, Wasserman et al. 2004 used data on a pool of 400 children aged between 9.5 and 10.5 years of which only 201-176 could be assessed for cognitive skills. The sample came from only one sub-district of Bangladesh-- Araihazar.

${ }^{6}$ Upon examination of a large sample $(\mathrm{N}=5000)$ of children below 11 years of age from the affected Bangladeshi villages, Chakraborti et al. (2004) found Arsenical skin lesions in 6.1\% of these children.
} 
Among other possibilities, parental time/resources could be diverted to care for sick brothers/sisters at home. The school performance of children from affected households can be also undermined if children are sent to fetch water which cuts into study hours at home. With nearly-complete awareness regarding the health implications of arsenicosis, affected households are increasingly seeking access to arsenic-free tubewells. Recent research on the choices of affected households in a highly contaminated region suggests that a majority have managed to switch to arsenic free water wells after learning about the contaminated state of their own tubewells ${ }^{7}$. Using data on households in the Araihazar sub-district, Madajewicz et al. (2007) find that $60 \%$ of the people whose wells were unsafe changed to another well within 12 months of receiving information by installing their own new well, using a neighbor's well, or a community well. In the latter two cases, affected households may send children to fetch water from safe wells. If so, learning outcomes can be adversely affected through impacting the time-allocation of school-going children between study and household chores $^{8}$. However, the seriousness of this problem is unclear, as arsenic contamination is highly irregular in a spatial sense. In many villages, unsafe tubewells are often near a safe well (van Geen et al, 2005) so that switching to the latter does not necessarily imply a significant increase in the distance travelled ${ }^{9}$.

\footnotetext{
${ }^{7}$ This finding is also consistent with the fact that tubewells still remain the main source of drinking water across rural Bangladesh. According to the Bangladesh Demographic and Health Survey (BDHS) 2007, 92\% (96\%) households in 2004 (2007) reported using tubewell as their main source of drinking water (NIPORT 2008).

${ }^{8}$ There is an international literature that highlights the importance of attendance and instructional time in predicting student achievement (e.g. Marcotte and Hemelt, 2008, 2010).

${ }_{9}^{9}$ Madajewicz et al. calculated the increase in travel time owing to tubewell switching in the Araihazar subdistrct, where seventy-seven percent of wells have arsenic concentrations which exceed the stricter WHO standard of $10 \mu \mathrm{g} /$ liter. Households who changed wells were found to have increased the time they spent walking for water by a modest 4.3 minutes for a round trip; the reported mean travel time after information campaign is 1 minute.
} 
In sum, apart from Wasserman et al. (2004; 2007), we are not aware of any study on the impact of arsenic contamination on children's cognitive performance in Bangladesh. Compared to Wasserman et al. which use sample from one sub-district where the majority of the population remains exposed to arsenic pollution, however, our study uses sample drawn from a large number of exposed and unexposed rural locations. Similar to Wasserman et al., we assess learning outcomes using an internationally comparable assessment tool. However, alongside cognitive outcomes, we also investigate the adverse effect of arsenic contamination by analyzing the subjective well-being of children. Furthermore, arsenic-exposed children in our data belong to two different schooling systems (non-religious vs. religious) which provide an interesting setting in which to study the adverse effect of water well contamination on children's cognitive development. To the best of our knowledge, there is no study on arsenic exposure and children's well-being (for any developing country) that has used data on a cohort of secondary school children enrolled in schools located in affected and unaffected areas. Therefore, our study complements existing research that uses a very small purposive sample but has detailed, rich data on the child's health conditions to measure exposure to arsenic contamination (e.g. Wasserman et al., 2004).

\section{$3 \quad$ Data and methodology}

\subsection{Sample and survey description}

The data used in this paper was collected by the authors in 2005. The primary sampling unit of the survey chosen was Unions ${ }^{10}$. To account for spatial variation in school participation rate and arsenic exposure, 60 Unions were selected with proportional

\footnotetext{
${ }^{10}$ Union is an administrative unit bigger than a village but smaller than sub-district.
} 
allocation from 6 divisions in the country. In the second step, for each sample Union, a complete list of secondary schools in our sample Unions was compiled. Using this list, all secondary educational institutes in each of the sample Union were selected for data collection. In sum, a simple clustered sampling procedure was followed to select schools for the survey. All registered non-religious schools and madrasas (i.e. Islamic religious schools) in each selected Union were surveyed. In total, 321 schools and madrasas were identified in the 60 Unions $^{11}$. A detailed description of survey methodology and sampling is available in Asadullah, Caudhury and Dar (2007).

Two mathematics tests were administered to all students, both boys and girls, enrolled in grade 8 and present on the day of the survey. The first test was based on secondary-standard mathematics knowledge while the second test instrument was based on the primary school mathematics syllabus ${ }^{12}$. If there were two classrooms in grade 8 , both were selected for participation in the maths test. However, if any of the schools had more than two classrooms, only two were randomly selected. Once again, all students present on the day of the survey were interviewed. Given the cluster-based sampling, the survey led to a near-census of all secondary school going children (currently enrolled in grade 8 and present on the day of the survey) in the sample Unions. The dataset contains a total of 321 schools and 8475 students. Data on 5 schools were discarded, however, due to problems of poor quality and missing data.

Each student taking the test was asked to answer a number of questions relating to their family and parental background. Detailed data on personal characteristics and the

\footnotetext{
${ }^{11}$ Registered secondary madrasas in Bangladesh follow state-approved curriculum and teach mathematics alongside religious studies. For further details, see Asadullah and Caudhury (2009).

12 The first test instrument was constructed by adopting 20 items previously used in the Trends in International Mathematics and Science Study (TIMSS), 1999.
} 
history of pre-secondary schooling (such as types of primary and pre-primary school attended) were also collected. For each school, the head teacher was interviewed to gather data on various aspects of the school including arsenic contamination of tubewells at school. If the head teacher was absent, the teacher-in-charge was interviewed. Additionally, school registers were accessed to collect data on student performance in final school examinations in grade 7 in the previous year.

To identify arsenic-affected children, we asked sample pupils whether tubewells at home were contaminated by arsenic. By the year 2004, the Government of Bangladesh had completed a nationwide census and screening of tubewells in the country. Following this exercise, wells with more than 50 micrograms of arsenic per litre were identified as contaminated and therefore painted red; those with less than 50 micrograms of arsenic were ascertained as being safe and hence painted green (BAMWSP, 2005). Therefore, contamination status was determined by asking children whether the tubewell at home was painted red or green. To be precise, we have used information on arsenic poisoning of the primary source of drinking water-tubewells - to ascertain arsenic exposure at the household-level. 
Table 1: Descriptive statistics by arsenic exposure at home

\section{Variable}

Outcomes

$\%$ of mathematics answer correct [secondary standard]

$\%$ of mathematics answer correct [primary standard]

Happy [1=very unhappy; 4= very happy]

\section{Personal attributes}

Age

Age, squared

Female*

Family background

Travel time to school from home (in minutes)

Father primary educated*

Father secondary educated*

Father post-secondary educated*

Mother primary educated*

Mother secondary educated*

Mother post-secondary educated*

Household has a fan

Household has a tv

Household has a radio

House is pucca (made of brick, cement and iron rod)*

House is semi-pucca*

Schooling history

Attended pre-primary (maktab) school in childhood*

Class rank in grade 7

Attended private primary school*

Attended primary madrasa*

Attended primary NGO school*

Attended primary grade in this school*

Secondary school attributes

Madrasa*

School tubewell arsenic-poisoned*

No tubewell in school*

$\mathrm{N}$

\begin{tabular}{|c|c|c|c|}
\hline \multicolumn{2}{|c|}{ Home tubewell arsenic-poisoned } & \multicolumn{2}{|c|}{ Home tubewell arsenic free } \\
\hline Mean & SD & Mean & SD \\
\hline 0.36 & 0.18 & 0.38 & 0.20 \\
\hline 0.74 & 0.29 & 0.78 & 0.27 \\
\hline 2.96 & 0.86 & 3.09 & 0.85 \\
\hline 13.07 & 0.92 & 13.25 & 0.95 \\
\hline 171.79 & 24.93 & 176.35 & 30.30 \\
\hline 0.60 & 0.49 & 0.62 & 0.49 \\
\hline 23.07 & 18.97 & 22.41 & 18.65 \\
\hline 0.34 & 0.47 & 0.33 & 0.47 \\
\hline 0.20 & 0.40 & 0.20 & 0.40 \\
\hline 0.19 & 0.39 & 0.24 & 0.43 \\
\hline 0.35 & 0.48 & 0.39 & 0.49 \\
\hline 0.21 & 0.41 & 0.18 & 0.38 \\
\hline 0.08 & 0.27 & 0.10 & 0.30 \\
\hline 0.31 & 0.46 & 0.37 & 0.48 \\
\hline 0.30 & 0.46 & 0.37 & 0.48 \\
\hline 0.53 & 0.50 & 0.58 & 0.49 \\
\hline 0.19 & 0.39 & 0.12 & 0.33 \\
\hline 0.14 & 0.35 & 0.16 & 0.36 \\
\hline 0.55 & 0.50 & 0.63 & 0.48 \\
\hline 22.82 & 21.36 & 22.11 & 21.74 \\
\hline 0.19 & 0.39 & 0.19 & 0.39 \\
\hline 0.06 & 0.24 & 0.05 & 0.21 \\
\hline 0.11 & 0.32 & 0.06 & 0.24 \\
\hline 0.03 & 0.16 & 0.03 & 0.18 \\
\hline 0.20 & 0.40 & 0.19 & 0.40 \\
\hline 0.02 & 0.15 & 0.01 & 0.12 \\
\hline 0.49 & 0.50 & 0.27 & 0.44 \\
\hline 860 & & 6619 & \\
\hline
\end{tabular}

Notes: * indicates a dummy (1/0) variable. Omitted class for parental education variable is "never went to school". Base category for house type and primary school type is "kacha" and "government primary school" respectively. The table excludes 231 children who do not have any tubewell at home. Base category for primary school type is "government primary school".

Our working sample comprises of 7710 students for whom we have complete data on test scores and arsenic contamination of tubewells at home ${ }^{13}$. Appendix Table 1 summarizes key variables of interest. $12 \%$ of sample children reported belonging to

\footnotetext{
${ }^{13} 13 \%$ of the actual sample observations were discarded due to missing data problems leading to a working sample of 7710 students.
} 
households with arsenic contaminated tubewells ${ }^{14}$. In general, the level of student achievement is very low in our sample. On average, students could correctly answer only $38 \%$ of secondary-standard maths questions. When looking at test scores by arsenic pollution status of tubewell at home, we find that children from affected households have systematically lower maths scores (both in secondary and primary-standard tests) and subjective well-being (happiness) (see Table 1). While these differences in outcomes by arsenic exposure are modest, they are always statistically significant (as confirmed by ttest of difference of means). We are interested to see whether these differences in raw data prevail even when we account for various conventional determinants of school performance and subjective well being such as socio-economic condition of the family, personal attributes, schooling history and school attributes (including arsenic contamination status of tubewells at secondary school). This is explored in section 4 which reports results from multivariate regression models. The next section describes the empirical strategy we follow in order to test the impact of arsenic contaminated drinking water well at home, a proxy for arsenicosis.

\subsection{Empirical framework}

We are interested to investigate the effect of water well contamination status on cognitive achievement and the psychological state of children enrolled in secondary schools. As mentioned earlier, the pollution is entirely natural (McArthur et al., 2001). The distribution of arsenic in rural Bangladesh is highly variable spatially but this variability is geological. Hence exposure to arsenic contaminated drinking water is exogenous. Nonetheless, identifying the causal effect of arsenic contamination in cross-section data

\footnotetext{
${ }^{14}$ This figure is highly comparable to available estimates based on household survey. For instance, according to BDHS 2004, 7.9\% of sample households had arsenic contaminated tubewells in rural Bangladesh.
} 
can be difficult for two reasons. First, a selection bias can exist if families chose to stay near a contaminated well. In other words, the better-off families would have more resources to move if their well was found to be poisoned and/or arrange for access to safe water from alternative sources. Thus those who remain could be a negatively selected group. If that is the case, the results could be driven by non-random migration away from poisoned wells.

In order to ensure that non-random geographic relocation is not biasing the observed correlation between well contamination and test score, we exploit timing of the first national water well screening program run by the government. Households can only abandon a tubewell once it has tested positive for arsenic. However, rural households do not have the financial means and technical ability to test for the presence of arsenic in domestic tubewells. They therefore relied on the government screening programme. By conducting the field work soon after completion of the national arsenic screening programme in 2004 , we are therefore able to minimize the possibility of non-random migration out of the affected area or non-random switching to safe water wells in our sample. Since our field work was conducted early in 2005, it is reasonable to expect across-the-board exposure to contaminated water well in affected households in our sample.

Second, even if bias owing to non-random migration away from affected regions is minimized, the actual effect of arsenicosis can be conditioned by a variety of socioeconomic factors. Mere exposure to polluted tubewells does not equally affect all children. The extent of the adverse effect depends on the total intake of poisoned water. Fluid intake on the other hand varies according to age, gender and amount of physical 
activities. Furthermore children who grow up in poorer households are likely to have poor health status and hence more susceptible to arsenic-caused illness. Even in the case of equal fluid intake, the impact may vary depending on the previous nutritional status of the child (e.g. zinc which repairs skin damage). A recent study using BDHS 2004 data confirms that drinking of arsenic contaminated water in poor socioeconomic groups is significantly higher, and poor people suffer from more arsenic toxicity (Khan et al., 2007). Therefore, it is important to control for demographic and socio-economic attributes of the child. To this end, we investigate the impact of arsenic polluted water wells on measures of learning outcomes and psychological well-being in the following regression framework:

Maths Score $_{i}=\beta^{\prime} X_{i}+\partial_{1}(\text { Home water well contaminated })_{i}+e_{i}$

In equation (1), $\mathrm{e}_{\mathrm{i}}$ is the idiosyncratic (student-specific) error term. The dependant variable is maths score of $i$-th student of grade 8 . The key parameter of interest is $\partial_{1}$, the coefficient on the dummy variable indicating contamination of water well at home. $X$ is a vector that includes controls for student and family-background characteristics (such as paternal and maternal education and household assets; gender and age of the child), school-specific attributes (such as school expenditure, whether the school is recognized, fraction of teachers trained and whether it is a single-sex school), and past schooling background of the student such type of the primary school attended, whether they attended religious school for pre-primary schooling and a proxy for past achievement (measured by the class rank of the student in grade 7 final examination administered by the school in 2004). Inclusion of controls for pre-primary education, and past school type 
therefore yields a pseudo value-added specification of the production function to the extent these correlates proxy for past educational inputs.

Given that our data is clustered at multiple levels (e.g. students within classrooms within schools), we adopt a fixed-effects (FE) regression framework instead of a simple ordinary least squares (OLS) model. To be precise, we estimate equation (1) as school FE regression and difference out all school specific variables including school-level exposure to arsenic contaminated water well. This yields a production function that is immune to possible selection bias owing to non-random assignment to non-religious schools ${ }^{15}$. This approach also provides a cleaner estimate of the effect of household-level exposure to arsenic. Additionally, we re-estimate equation (1) controlling for classroom fixed effects. Observable characteristics of children attending the same school/class should be comparable. Therefore, as long as observed characteristics matter for actual exposure to arsenic contaminated water at home, comparing children in the same classroom provides a convenient way to test whether residing near a poisoned well causes decreased student achievement.

For two reasons, there is significant spatial variation in arsenic exposure in our sample so that fixed-effects approach is feasible. Students in our sample not only come from a large number of villages, there is considerable geographic variation in groundwater arsenic within villages independent of socio-economic profile of the household. First, our sample of 321 schools, spread over 900 villages, is drawn from 60 Unions. An average Union in rural Bangladesh has 5 secondary schools (religious \& nonreligious) that are spread over 15 villages. This means that children in an average sample

\footnotetext{
${ }^{15}$ Evidence of such bias arising due to selection in a religious on the basis of socio-economic background of the child school is documented in Asadullah, Chaudhury and Dar (2007).
} 
school come from multiple villages which ensure variation in exposure to arsenic contaminated water wells among children enrolled in the same school and/or classroom. Second, there is a significant small-scale variability within villages concerning the extent of arsenic concentrations in groundwater, which is uncorrelated with household landholding size and quality (Yu, Harvey and Harvey, 2003). According to van Geen et al. (2003), an estimated $88 \%$ of contaminated wells are located within 100 meters of an uncontaminated well, giving rise to substantial within-village variation in contamination. For the above reasons, even when we restrict test scores comparison to students enrolled in the same school or classroom, significant variation in arsenic exposure remains. Therefore, our identification strategy relies on within school and classroom variation in arsenic exposure.

In sum, in our main analysis, we estimate the following two reduced form equations:

Maths Score $_{\text {is }}=\beta^{\prime} X_{\text {is }}+\partial_{2}(\text { Home water well contaminated })_{\text {is }}+v_{\mathrm{s}}+\varepsilon_{\text {is }}$

Maths Score $_{\mathrm{ic}}=\beta^{\prime} \mathrm{X}_{\mathrm{ic}}+\partial_{3}(\text { Home water well contaminated })_{\mathrm{ic}}+\mathrm{w}_{\mathrm{c}}+\mathrm{u}_{\mathrm{ic}}$

where, $\mathrm{v}_{\mathrm{S}}$ is the vector of school fixed effects and $\mathrm{v}_{\mathrm{C}}$ is the vector of classroom fixed effects. In equations (2) and (3), we expect $\partial_{2}$ and $\partial_{3}$ to be negatively signed respectively. The significance of our estimates would indicate an adverse impact of arsenic exposure on learning outcomes. As a robustness check, we alter the dependent variable and use test scores in primary-standard mathematics as an outcome variable ${ }^{16}$. Furthermore, we use

\footnotetext{
${ }^{16}$ As part of this test, students were given 4 maths questions which were based on primary school mathematics curriculum.
} 
data on subjective-well being ${ }^{17}$ to form an additional dependent variable and examine the effect of arsenic exposure in drinking water. The next section reports the regression estimates of equation (2) and (3) using a total of 3 outcome measures.

\section{$4 \quad$ Arsenic poisoning and student achievement}

\subsection{Main Results}

Table 2 reports the main regression results using standardized test scores ${ }^{18}$. Two sets of FE estimates, namely school and classroom FEs, are reported where for each of set, we use a parsimonious (without controlling for individual and family background), and a detailed model (with full control for various individuals, school and family factors). The school FE specification, by definition, controls for arsenic poisoning of tubewells at school. Therefore, this yields estimates of household-level exposure to arsenic poisoning net of school-level exposure.

Table 2: Determinants of student achievement (secondary-standard maths test scores)

\begin{tabular}{lcccc} 
& \multicolumn{2}{c}{ School FE } & \multicolumn{2}{c}{ Classroom FE } \\
\cline { 2 - 5 } Home tubewell arsenic-poisoned & $(1)$ & $(2)$ & $(3)$ & $(4)$ \\
\cline { 2 - 5 } Age & $-0.064^{*}$ & $-0.046^{+}$ & $-0.06^{*}$ & $-0.044+$ \\
& $(2.38)$ & $(1.83)$ & $(2.27)$ & $(1.78)$ \\
Age squared & & -0.003 & & -0.003 \\
& & $(0.53)$ & & $(0.51)$ \\
Female & 0.000 & 0.000 \\
& & $(0.10)$ & $(0.06)$ \\
Father primary educated & $-0.086^{* *}$ & $-0.085^{* *}$ \\
Father secondary educated & $(5.51)$ & $(5.08)$ \\
Father post-secondary educated & -0.015 & -0.016 \\
& & $(0.78)$ & $(0.87)$ \\
& & 0.023 & 0.024 \\
& & $(1.06)$ & $(1.11)$ \\
\end{tabular}

\footnotetext{
${ }^{17}$ There is a small number of empirical studies that have used subjective response data to model economic behaviour. For a review, see Tella and MacCulloch (2006).

${ }^{18}$ Test scores are standardized to a sample-wide mean of zero and variance equal to 1 .
} 


\begin{tabular}{|c|c|c|c|c|}
\hline Mother primary educated & & $\begin{array}{l}0.037^{*} \\
(2.23)\end{array}$ & & $\begin{array}{l}0.036^{*} \\
(2.19)\end{array}$ \\
\hline Mother secondary educated & & $\begin{array}{c}0.038+ \\
(1.79)\end{array}$ & & $\begin{array}{l}0.04+ \\
(1.90)\end{array}$ \\
\hline Mother post-secondary educated & & $\begin{array}{c}0.074 * * \\
(2.64)\end{array}$ & & $\begin{array}{l}0.072 * \\
(2.56)\end{array}$ \\
\hline Household has a fan & & $\begin{array}{c}0.033+ \\
(1.83)\end{array}$ & & $\begin{array}{r}0.030+ \\
(1.65)\end{array}$ \\
\hline Household has a TV & & $\begin{array}{l}0.017 \\
(0.98)\end{array}$ & & $\begin{array}{l}0.015 \\
(0.91)\end{array}$ \\
\hline Household has a radio & & $\begin{array}{l}-0.005 \\
(0.36)\end{array}$ & & $\begin{array}{l}-0.005 \\
(0.38)\end{array}$ \\
\hline House is pucca & & $\begin{array}{l}-0.018 \\
(0.78)\end{array}$ & & $\begin{array}{l}-0.012 \\
(0.52)\end{array}$ \\
\hline House is semi-pucca & & $\begin{array}{l}-0.005 \\
(0.25)\end{array}$ & & $\begin{array}{l}-0.003 \\
(0.13)\end{array}$ \\
\hline Travel time to school from home & & $\begin{array}{l}-0.000 \\
(1.24)\end{array}$ & & $\begin{array}{l}-0.000 \\
(0.99)\end{array}$ \\
\hline Constant & $\begin{array}{l}-0.047 \\
(0.39) \\
\end{array}$ & $\begin{array}{l}-0.109 \\
(0.46)\end{array}$ & $\begin{array}{c}0 \\
(0.06) \\
\end{array}$ & $\begin{array}{l}0.267 \\
(1.23) \\
\end{array}$ \\
\hline $\mathrm{N}$ & 7710 & 7710 & 7710 & 7710 \\
\hline $\begin{array}{l}\text { R-squared } \\
\text { Control for schooling history? }\end{array}$ & $\begin{array}{l}0.00 \\
\text { No }\end{array}$ & $\begin{array}{l}0.04 \\
\text { Yes }\end{array}$ & $\begin{array}{c}0.00 \\
\text { No }\end{array}$ & $\begin{array}{l}0.04 \\
\text { Yes }\end{array}$ \\
\hline
\end{tabular}

Notes: (a) Absolute value of t-statistics in parentheses (using robust standard errors). + significant at 10\%; * significant at 5\%; ** significant at $1 \%$. (b) Each regression additionally contains a dummy indicating tubewell non-availability at home. (c) Variables capturing "schooling history" are class size in grade 7, rank in examination in the previous grade, type of primary school attended and whether the child received pre-school religious education.

The parsimonious specification (column 1) yields a negative and statistically significant coefficient on the dummy "arsenic contaminated of water well at home". This negative correlation between mathematics scores and arsenic contamination status of water wells at home prevails even when we fully control for past school inputs and family background (column 2). Additionally, we find the effect of household-level poisoning by arsenic to be robust to controls for classroom level unobservable determinant of learning (column 3). To the extent students in a classroom attended the same primary school, control for classroom FE helps negate any effect of past exposure to arsenic contaminated water wells at primary school. However, once we fully control for individual and family 
background factors, school and classroom FE estimates return a much smaller coefficient (albeit significant at 10\% level) on the arsenic exposure variable (columns 2 and 4).

Similar correlations are found for an alternative measure of achievement in mathematics. Table 3 once again reports two sets of FE estimates using parsimonious and detailed specifications. Irrespective of whether we control for school FE or classroom FE, we find a negative, statistically significant coefficient on arsenic exposure variable in the detailed specification. This finding therefore corroborates our earlier analysis of data on student achievement in secondary-standard tests. However, the effect is greater in the case of primary mathematics. Children with arsenic poisoned tubewell at home have around 0.04 standard deviations lower scores in secondary mathematics than their peers with safe tubewell, and it is around 0.09 standard deviations lower in primary mathematics.

Additionally, we investigate the effect of arsenic contaminated water wells at home on the subjective well-being of children i.e. self-reported measure of life satisfaction of students (see Table 4). Once again, the coefficient on arsenic exposure variable is consistently negative, irrespective of the choice of estimation techniques (i.e. school or classroom FEs).

Table 3: Determinants of student achievement (primary-standard maths test scores)

\begin{tabular}{lcccc}
\hline & \multicolumn{2}{c}{ School FE } & \multicolumn{2}{c}{ Classroom FE } \\
\cline { 2 - 5 } Home tubewell arsenic-poisoned & $(1)$ & $(2)$ & $(1)$ & $(2)$ \\
\cline { 2 - 5 } & $-0.057^{*}$ & $-0.088^{*}$ & $-0.11^{*}$ & $-0.085^{*}$ \\
Age & $(2.15)$ & $(2.53)$ & $(2.44)$ & $(2.45)$ \\
& & 0.005 & & 0.006 \\
Age squared & & $(0.13)$ & & $(0.15)$ \\
\multirow{2}{*}{ Female } & & -0.001 & & -0.001 \\
& & $(0.44)$ & & $(0.45)$ \\
Father up to primary educated & & $-0.342^{* *}$ & & $-0.337^{* *}$ \\
& & $(15.68)$ & & $(14.30)$ \\
\end{tabular}




\begin{tabular}{|c|c|c|c|c|}
\hline & & $(0.56)$ & & $(0.45)$ \\
\hline \multirow[t]{2}{*}{ Father up to secondary educated } & & $0.06^{*}$ & & $0.063 *$ \\
\hline & & (1.98) & & $(2.11)$ \\
\hline \multirow[t]{2}{*}{ Father post-secondary educated } & & $0.053+$ & & $0.053+$ \\
\hline & & $(1.68)$ & & $(1.67)$ \\
\hline \multirow[t]{2}{*}{ Mother up to primary educated } & & 0.016 & & 0.014 \\
\hline & & $(0.71)$ & & $(0.59)$ \\
\hline \multirow[t]{2}{*}{ Mother up to secondary educated } & & 0.039 & & 0.044 \\
\hline & & $(1.31)$ & & $(1.48)$ \\
\hline \multirow[t]{2}{*}{ Mother post-secondary educated } & & $0.067+$ & & 0.064 \\
\hline & & $(1.70)$ & & $(1.63)$ \\
\hline \multirow[t]{2}{*}{ Household has a fan } & & $0.067 * *$ & & $0.066^{* *}$ \\
\hline & & $(2.63)$ & & $(2.61)$ \\
\hline \multirow[t]{2}{*}{ Household has a TV } & & 0.009 & & 0.009 \\
\hline & & $(0.38)$ & & $(0.38)$ \\
\hline \multirow[t]{2}{*}{ Household has a radio } & & 0.018 & & 0.02 \\
\hline & & $(0.89)$ & & $(1.02)$ \\
\hline \multirow[t]{2}{*}{ House is pucca } & & -0.003 & & -0.001 \\
\hline & & $(0.11)$ & & $(0.02)$ \\
\hline \multirow[t]{2}{*}{ House is semi-pucca } & & -0.027 & & -0.03 \\
\hline & & $(0.92)$ & & $(1.05)$ \\
\hline \multirow[t]{2}{*}{ Travel time to school from home } & & $-0.002 * *$ & & $-0.002 * *$ \\
\hline & & $(3.15)$ & & $(2.84)$ \\
\hline \multirow[t]{2}{*}{ Constant } & 0.001 & 0.035 & $0.027 * *$ & 0.336 \\
\hline & $(0.07)$ & $(0.11)$ & $(3.27)$ & $(1.11)$ \\
\hline $\mathrm{N}$ & 7710 & 7710 & 7710 & 7710 \\
\hline R-squared & 0.00 & 0.07 & 0.00 & 0.06 \\
\hline Control for schooling history? & No & Yes & No & Yes \\
\hline
\end{tabular}

Notes: (a) Absolute value of t-statistics in parentheses (using robust standard errors). + significant at 10\%; * significant at 5\%; ** significant at $1 \%$. (b) Each regression additionally contains a dummy indicating tubewell non-availability at home. (c) Variables capturing "schooling history" are class size in grade 7, rank in examination in the previous grade, type of primary school attended and whether the child received pre-school religious education. 
Table 4: Determinants of happiness (dependent variable: 4=very happy; 1 = very unhappy)

\begin{tabular}{|c|c|c|c|c|}
\hline \multirow{3}{*}{ Home tubewell arsenic-poisoned } & \multicolumn{2}{|c|}{ School FE } & \multicolumn{2}{|c|}{ Classroom FE } \\
\hline & $(1)$ & $(2)$ & (1) & $(2)$ \\
\hline & $\begin{array}{c}-0.12^{* *} \\
(3.06)\end{array}$ & $\begin{array}{c}-0.10^{* *} \\
(2.97)\end{array}$ & $\begin{array}{c}-0.119 * * \\
(2.95)\end{array}$ & $\begin{array}{c}-0.098^{* *} \\
(2.93)\end{array}$ \\
\hline Age & & $\begin{array}{c}-0.063+ \\
(1.77)\end{array}$ & & $\begin{array}{c}-0.065+ \\
(1.84)\end{array}$ \\
\hline Age squared & & $\begin{array}{l}0.001 \\
(1.29)\end{array}$ & & $\begin{array}{l}0.001 \\
(1.33)\end{array}$ \\
\hline Female & & $\begin{array}{c}0.172^{* *} \\
(8.25)\end{array}$ & & $\begin{array}{c}0.186^{* *} \\
(8.21)\end{array}$ \\
\hline Father primary educated & & $\begin{array}{l}-0.02 \\
(0.79)\end{array}$ & & $\begin{array}{l}-0.021 \\
(0.86)\end{array}$ \\
\hline Father secondary educated & & $\begin{array}{c}0.03 \\
(1.05)\end{array}$ & & $\begin{array}{l}0.032 \\
(1.11)\end{array}$ \\
\hline Father post-secondary educated & & $\begin{array}{c}0.063^{*} \\
(2.07)\end{array}$ & & $\begin{array}{l}0.063 * \\
(2.09)\end{array}$ \\
\hline Mother primary educated & & $\begin{array}{l}0.024 \\
(1.08)\end{array}$ & & $\begin{array}{l}0.022 \\
(1.00)\end{array}$ \\
\hline Mother secondary educated & & $\begin{array}{l}0.028 \\
(1.01)\end{array}$ & & $\begin{array}{c}0.03 \\
(1.07)\end{array}$ \\
\hline Mother post-secondary educated & & $\begin{array}{c}0.071+ \\
(1.87)\end{array}$ & & $\begin{array}{c}0.067+ \\
(1.78)\end{array}$ \\
\hline Household has a fan & & $\begin{array}{c}0.043+ \\
(1.76)\end{array}$ & & $\begin{array}{c}0.041+ \\
(1.71)\end{array}$ \\
\hline Household has a TV & & $\begin{array}{c}0.127^{* *} \\
(5.54)\end{array}$ & & $\begin{array}{c}0.126^{* *} \\
(5.49)\end{array}$ \\
\hline Household has a radio & & $\begin{array}{c}0.061^{* *} \\
(3.22)\end{array}$ & & $\begin{array}{c}0.061^{* *} \\
(3.24)\end{array}$ \\
\hline House is pucca & & $\begin{array}{c}0.114^{* *} \\
(3.78)\end{array}$ & & $\begin{array}{c}0.115^{* *} \\
(3.81)\end{array}$ \\
\hline House is semi-pucca & & $\begin{array}{c}0.087^{* *} \\
(3.14)\end{array}$ & & $\begin{array}{c}0.082 * * \\
(2.96)\end{array}$ \\
\hline Travel time to school from home & & $\begin{array}{c}0 \\
(0.59)\end{array}$ & & $\begin{array}{c}0 \\
(0.6)\end{array}$ \\
\hline Constant & $\begin{array}{l}3.112^{* *} \\
(414.84) \\
\end{array}$ & $\begin{array}{r}3.445^{* *} \\
(10.94) \\
\end{array}$ & $\begin{array}{l}3.112^{* *} \\
(397.36) \\
\end{array}$ & $\begin{array}{r}3.402 * * \\
(11.69) \\
\end{array}$ \\
\hline $\mathrm{N}$ & 7606 & 7606 & 7606 & 7606 \\
\hline R-squared & 0.00 & 0.04 & 0.00 & 0.04 \\
\hline Control for schooling history? & No & Yes & No & Yes \\
\hline
\end{tabular}

Notes: (a) Absolute value of t-statistics in parentheses (using robust standard errors). + significant at 10\%; * significant at $5 \%$; ** significant at $1 \%$. (b) Each regression additionally contains a dummy indicating tubewell non-availability at home. (c) Variables capturing "schooling history" are class size in grade 7, rank in examination in the previous grade, type of primary school attended and whether the child received pre-school religious education. 
Estimates of the effect of household-level arsenic exposure presented in Tables 2 and 3 do not tell us anything about the particular pathways through which arsenic exposure adversely affects children's learning outcomes. To be precise, we do not know whether children are affected because arsenic exposure (a) lowers cognitive ability, (b) leads to various skin diseases which socially ostracises students at school, or (c) makes children more susceptible to various other diseases thereby adversely affecting their health status. In the absence of a direct measure of ability (such as Raven's score), anthropometric measures of past and present health status and data on physical symptoms of arsenic poisoning, it is not possible to distinguish between these competing hypotheses. Nonetheless, we carry out a crude test in an attempt to separate out the socialization hypothesis from other competing explanations.

According to the socialization hypothesis, children with visible signs of arsenicosis may be ostracised at school and hence feel traumatised, and thus underperform. To the extent there are school-level differences in norms (administrative rules and policies such as separate common room for boys and girls), and dress-codes (fulllength cover of the body only exposing eyes or face vs. traditional wear completely exposing arm and face), looking across non-religious and religious school sub-samples (having controlled for school-specific factors) would help us separate the adverse effect of arsenicosis arising via social interactions channel, from other channels such as health. The socialization hypothesis of arsenicosis is irrelevant for Islamic schools as they maintain strict dress code for boys as well as girls, covering the whole body and known to practice disciplinary rules limiting bullying and teasing at school. Indeed, raw data on 
arsenic penalty by school type corroborates this hypothesis - student scores in mathematics tests are always lower for children who report the home tubewell to be contaminated but it is only significantly so for the sample of non-religious school children (see Appendix Table 2). As a formal test of this proposition, we separately estimated the impact of arsenic exposure at home, for the sample of Islamic and nonreligious school students, on maths and well-being scores, controlling for school characteristics and past educational background of the student (regressions reported in Table 5). Indeed, for madrasa students in our dataset, there is no statistically significant effect of arsenic poisoning at home. However, the effect is negative and statistically significant for school sample where children are not subjected to restrictions on dress code and have greater opportunity to ostracise someone on the basis of his/her physical/personal attributes. Similar results are obtained for these sub-samples if we repeat the analysis using other outcome measures such as subjective wellbeing status and student performance in the alternative mathematics test. Children with arsenic poisoned tubewell at home have around 0.07 standard deviations lower scores in secondary mathematics than their peers with safe tubewells. The effect is even a bigger negative, 0.20 standard deviations lower, in primary mathematics. Our finding tends to support existing claims in the literature that arsenicosis limits the scope of socialization and therefore can harm children's development (Hassan et al., 2005). 
Table 5: Determinants of student achievement (maths test scores) and happiness by school type (OLS estimates)

\begin{tabular}{|c|c|c|c|c|c|c|}
\hline & \multicolumn{2}{|c|}{$\begin{array}{c}\text { Secondary-standard } \\
\text { test scores }\end{array}$} & \multicolumn{2}{|c|}{$\begin{array}{c}\text { Primary-standard } \\
\text { test scores }\end{array}$} & \multicolumn{2}{|c|}{ Happiness } \\
\hline & Islamic & $\begin{array}{l}\text { Non- } \\
\text { religious }\end{array}$ & Islamic & $\begin{array}{c}\text { Non- } \\
\text { religious }\end{array}$ & Islamic & $\begin{array}{l}\text { Non- } \\
\text { religious }\end{array}$ \\
\hline Home tubewell arsenic-poisoned & $\begin{array}{l}0.041 \\
(0.62)\end{array}$ & $\begin{array}{c}-0.074^{*} \\
(2.01)\end{array}$ & $\begin{array}{l}0.158 \\
(1.69)\end{array}$ & $\begin{array}{c}-0.177^{* *} \\
(4.64)\end{array}$ & $\begin{array}{c}-0.169+ \\
(1.94)\end{array}$ & $\begin{array}{c}-0.121^{* *} \\
(2.78)\end{array}$ \\
\hline Age & $\begin{array}{c}0.112 * * \\
(3.06)\end{array}$ & $\begin{array}{l}0.266 \\
(1.13)\end{array}$ & $\begin{array}{l}0.088 \\
(1.68)\end{array}$ & $\begin{array}{c}0.485+ \\
(1.98)\end{array}$ & $\begin{array}{l}-0.049 \\
(0.72)\end{array}$ & $\begin{array}{l}-0.209 \\
(0.88)\end{array}$ \\
\hline Age squared & $\begin{array}{c}-0.003^{* *} \\
(3.46)\end{array}$ & $\begin{array}{l}-0.011 \\
(1.34)\end{array}$ & $\begin{array}{c}-0.002 \\
(2.02)+\end{array}$ & $\begin{array}{c}-0.019 * \\
(2.15)\end{array}$ & $\begin{array}{l}0.002 \\
(1.35)\end{array}$ & $\begin{array}{l}0.006 \\
(0.71)\end{array}$ \\
\hline Female & $\begin{array}{l}-0.048 \\
(0.78)\end{array}$ & $\begin{array}{c}-0.056 \\
(1.1)\end{array}$ & $\begin{array}{c}-0.198 * \\
(2.09)\end{array}$ & $\begin{array}{c}-0.367^{* *} \\
(6.33)\end{array}$ & $\begin{array}{l}0.094 \\
(1.16)\end{array}$ & $\begin{array}{c}0.188 * * \\
(4.81)\end{array}$ \\
\hline Father primary educated & $\begin{array}{l}0.012 \\
(0.24)\end{array}$ & $\begin{array}{l}-0.036 \\
(1.31)\end{array}$ & $\begin{array}{l}-0.022 \\
(0.38)\end{array}$ & $\begin{array}{l}0.017 \\
(0.54)\end{array}$ & $\begin{array}{l}0.045 \\
(0.89)\end{array}$ & $\begin{array}{l}-0.047 \\
(1.43)\end{array}$ \\
\hline Father secondary educated & $\begin{array}{l}-0.021 \\
(0.38)\end{array}$ & $\begin{array}{c}0.023 \\
(0.7)\end{array}$ & $\begin{array}{l}-0.05 \\
(0.82)\end{array}$ & $\begin{array}{c}0.067+ \\
(1.78)\end{array}$ & $\begin{array}{l}0.036 \\
(0.51)\end{array}$ & $\begin{array}{l}-0.016 \\
(0.36)\end{array}$ \\
\hline Father post-secondary educated & $\begin{array}{l}0.032 \\
(0.49)\end{array}$ & $\begin{array}{c}0 \\
(0.01)\end{array}$ & $\begin{array}{l}-0.02 \\
(0.27)\end{array}$ & $\begin{array}{c}0.05 \\
(1.18)\end{array}$ & $\begin{array}{c}0.01 \\
(0.15)\end{array}$ & $\begin{array}{l}0.051 \\
(1.01)\end{array}$ \\
\hline Mother primary educated & $\begin{array}{l}-0.025 \\
(0.53)\end{array}$ & $\begin{array}{l}0.033 \\
(1.07)\end{array}$ & $\begin{array}{l}0.053 \\
(1.11)\end{array}$ & $\begin{array}{c}0.02 \\
(0.66)\end{array}$ & $\begin{array}{l}0.096 \\
(1.54)\end{array}$ & $\begin{array}{l}0.027 \\
(0.97)\end{array}$ \\
\hline Mother secondary educated & $\begin{array}{l}-0.083 \\
(1.18)\end{array}$ & $\begin{array}{l}0.014 \\
(0.34)\end{array}$ & $\begin{array}{l}-0.009 \\
(0.11)\end{array}$ & $\begin{array}{l}0.056 \\
(1.44)\end{array}$ & $\begin{array}{l}0.096 \\
(1.36)\end{array}$ & $\begin{array}{l}0.011 \\
(0.34)\end{array}$ \\
\hline Mother post-secondary educated & $\begin{array}{l}-0.12+ \\
(2.01)\end{array}$ & $\begin{array}{c}0.099+ \\
(1.70)\end{array}$ & $\begin{array}{l}0.027 \\
(0.39)\end{array}$ & $\begin{array}{l}0.069 \\
(1.21)\end{array}$ & $\begin{array}{l}0.131 \\
(1.24)\end{array}$ & $\begin{array}{l}0.066 \\
(1.46)\end{array}$ \\
\hline Household has a fan & $\begin{array}{c}0.07 \\
(0.96)\end{array}$ & $\begin{array}{l}0.006 \\
(0.15)\end{array}$ & $\begin{array}{c}0.08 \\
(1.44)\end{array}$ & $\begin{array}{l}0.065 \\
(1.58)\end{array}$ & $\begin{array}{l}-0.011 \\
(0.22)\end{array}$ & $\begin{array}{l}0.001 \\
(0.04)\end{array}$ \\
\hline Household has a TV & $\begin{array}{l}-0.036 \\
(0.70)\end{array}$ & $\begin{array}{l}0.021 \\
(0.65)\end{array}$ & $\begin{array}{c}0.03 \\
(0.49)\end{array}$ & $\begin{array}{l}-0.022 \\
(0.61)\end{array}$ & $\begin{array}{l}0.004 \\
(0.09)\end{array}$ & $\begin{array}{c}0.162 * * \\
(5.17)\end{array}$ \\
\hline Household has a radio & $\begin{array}{l}0.038 \\
(1.09)\end{array}$ & $\begin{array}{l}0.003 \\
(0.11)\end{array}$ & $\begin{array}{l}0.043 \\
(1.08)\end{array}$ & $\begin{array}{l}0.021 \\
(0.89)\end{array}$ & $\begin{array}{l}0.012 \\
(0.26)\end{array}$ & $\begin{array}{l}0.07^{*} \\
(2.58)\end{array}$ \\
\hline House is pucca & $\begin{array}{l}0.072 \\
(0.84)\end{array}$ & $\begin{array}{l}-0.007 \\
(0.22)\end{array}$ & $\begin{array}{l}0.077 \\
(1.33)\end{array}$ & $\begin{array}{l}-0.048 \\
(1.14)\end{array}$ & $\begin{array}{l}0.037 \\
(0.35)\end{array}$ & $\begin{array}{c}0.139 * * \\
(3.01)\end{array}$ \\
\hline House is semi-pucca & $\begin{array}{l}0.036 \\
(0.57)\end{array}$ & $\begin{array}{l}-0.002 \\
(0.06)\end{array}$ & $\begin{array}{l}-0.018 \\
(0.19)\end{array}$ & $\begin{array}{l}-0.033 \\
(0.82)\end{array}$ & $\begin{array}{l}0.066 \\
(1.22)\end{array}$ & $\begin{array}{c}0.091^{*} \\
(2.44)\end{array}$ \\
\hline Travel time to school from home & $\begin{array}{l}0.002 \\
(1.64)\end{array}$ & $\begin{array}{c}-0.001 \\
(1.85)+\end{array}$ & $\begin{array}{l}-0.001 \\
(0.39)\end{array}$ & $\begin{array}{c}-0.002 * \\
(2.24)\end{array}$ & $\begin{array}{l}0.002 \\
(1.13)\end{array}$ & $\begin{array}{c}0 \\
(0.32)\end{array}$ \\
\hline Constant & $\begin{array}{r}-1.712 \\
(1.22) \\
\end{array}$ & $\begin{array}{l}-1.818 \\
(0.85) \\
\end{array}$ & $\begin{array}{l}-0.964 \\
(0.63) \\
\end{array}$ & $\begin{array}{c}-4.878 * * \\
(3.03) \\
\end{array}$ & $\begin{array}{c}5.589 * * \\
(4.81) \\
\end{array}$ & $\begin{array}{c}5.263^{* *} \\
(3.31) \\
\end{array}$ \\
\hline $\mathrm{N}$ & 1526 & 6184 & 1526 & 6184 & 1518 & 6088 \\
\hline R-squared & 0.03 & 0.05 & 0.03 & 0.08 & 0.01 & 0.05 \\
\hline $\begin{array}{l}\text { Control for schooling history and } \\
\text { school characteristics? }\end{array}$ & Yes & Yes & Yes & Yes & Yes & Yes \\
\hline
\end{tabular}

school characteristics?

Notes: (a) Absolute value of t-statistics in parentheses. + significant at 10\%; * significant at 5\%; ** significant at 1\%. (b) Each regression additionally contains dummies indicating tubewell non-availability in school and at home; whether tubewell at school is arsenic-contaminated; a set of 5 dummies indicating which day of the week the test was taken; regional dummies; and school characteristics (such as school 
expenditure, whether the school is recognized, fraction of teachers trained and whether it is a single-sex school). (c) All regressions use cluster-robust standard errors (clustered at the school level).

\subsection{Reliability of self-reported data on contamination status and additional robustness tests}

A major concern relating to the preceding analysis is that our measure of arsenic contamination is based on self-reported data. This implies that the child's reported exposure to arsenic contamination may be measured with error. In the absence of individual-level water well contamination data for our sample children, we are unable to directly address this issue.

However, we were able to access the nationwide database on water well tests carried out by the Government of Bangladesh in collaboration with various donor agencies. For all affected regions ${ }^{19}$, the National Arsenic Mitigation Information Center (NAMIC) maintains this database which provides information on the percentage of water wells that are contaminated by arsenic. Contamination status was ascertained on the basis of a formal test for the presence of arsenic in the drinking water. From the NAMIC database, we extracted information on the extent of arsenic contamination in our sample sub-districts. Appendix Figure 1 shows geographic distribution of all our sample sites while Appendix Figure 2 indicates the extent of arsenic contamination of water wells in each sample site. As per NAMIC data, 61\% of our sample Unions (37 out of 60) is affected by arsenic contamination. If self-reported data on contamination status is valid, it must be positively associated with official data on contamination status of the sample Unions.

\footnotetext{
19 Areas were declared as affected following a large-scale screening of water wells for arsenic contamination through the Bangladesh Arsenic Mitigation Water Supply Project (BAMWSP) of the Government of Bangladesh.
} 
When the distribution of sample children across affected and unaffected areas was examined, it was clear that as much as 59\% of the sample children (4569 out of 7710) attend school in affected areas (see Appendix Table 3). In addition, 12\% of the total sample (i.e. 925 children) report having contaminated wells at home and $70 \%$ of these children belong to the 37 sample Unions that are also officially declared as arsenic affected. The remaining 30\% (i.e. 277 children) reporting a contaminated well at home attends schools located in arsenic free (as per NAMIC records) Unions. This is explained by the fact that a sizable proportion of children in our dataset attend schools from nearby (non-sample) Unions which could be arsenic affected ${ }^{20}$.

Appendix Table 3 does not tell us how well self-reported data on arsenic exposure is correlated with BAMWSP data on the extent of contamination in sample Unions. If children correctly relate the red-label on the home tubewell with the presence of arsenic in the well water, then more children are likely to report affirmatively in areas that are also officially declared as most affected. At the same time, it is also unknown how much variation there is in terms of actual contamination of water wells across the sample Unions in the officially affected areas. To this end, Table 6 presents the distribution of self-reported data on water well contamination status across only affected sample Unions. There is clearly considerable variation across sample sites in terms of official arsenic contamination data. For example, 5\% of our sample children belong to sample Unions where $80 \%$ of the water wells are officially declared as arsenic contaminated. Moreover, looking at this distribution, there is a very clear positive correlation with official

\footnotetext{
${ }^{20}$ We asked children about the location of their households if it was outside the sample Union but within the sample sub-district. Altogether, 83\% (of 277) children belong to sub-districts that are affected by arsenic For 45 students, however, arsenic contamination status of their Union of residence could not be ascertained as they reported living in areas outside the sample sub-district.
} 
contamination data: children belonging to areas which are officially labelled as being highly affected by arsenic pollution are more likely to report home tubewell being arsenic-contaminated.

Table 6: Distribution of self-reported arsenic exposure data within affected region (based on official tests)

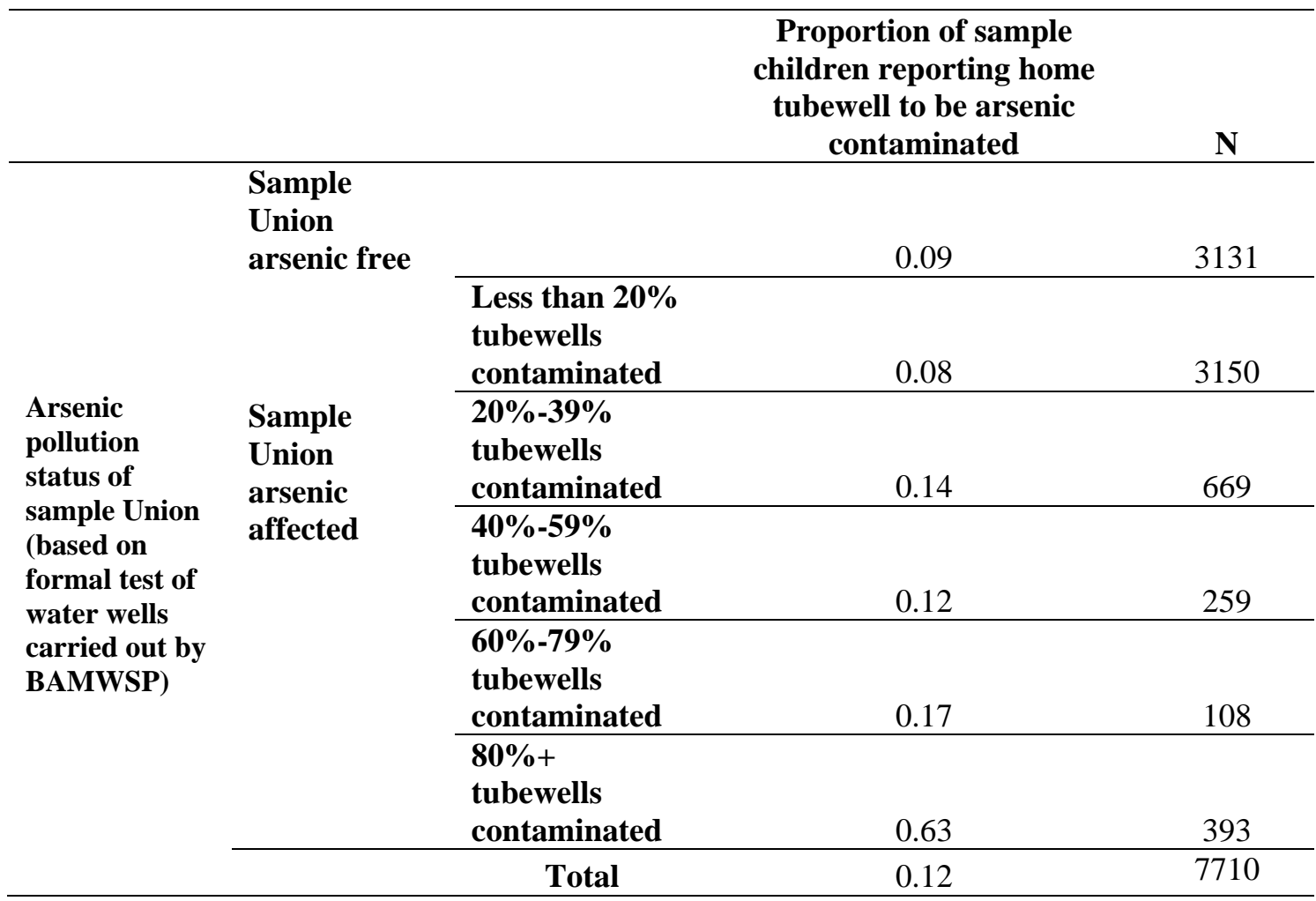

Note: (a) Self-reported data on arsenic contamination is based on home tubewell being reported to be painted "red". (b) A tubewell is identified as officially contaminated by BAMWSP if Arsenic concentration is found to be above 0.5 micro-gram per litre $(\mu \mathrm{g} / \mathrm{l})$.

In sum, our detailed analysis confirms the validity of our individual level selfreported arsenic contamination data: (a) 50\% of our sample children belong to arsenic affected regions (on the basis of official screening tests of water wells); (b) individual level indicator of exposure is highly correlated with official aggregate-level contamination data on water wells; (c) children in the highly (based on government 
assessment/test) affected areas are more likely to report that water wells at home are arsenic poisoned.

The validity of our self-reported indicator of water well contamination status at home is further confirmed by two additional regression-based tests. First, we re-estimated all the regression models reported in Tables 2-5 by discarding data on 65 children who reported having a contaminated well at home, but for whom arsenic contamination of their region of residence is unknown. Exclusion of these children from the analysis did not alter our previous findings. Second, we repeated our analysis by restricting data to sample Unions that, according to official screening tests, have a high level of arsenic exposure. In other words, we only purged the 60 sample Unions off those which are officially declared as affected Unions, but where the percentage of affected tubewells is not more than 50. Once again, the negative correlation between test scores and our selfreported indicator of home tubewell contamination holds for this smaller sample. More importantly, the institution-wise sub-sample analysis using this parsimonious set of sample observations reveals that the arsenic penalty is specific to schools; for madrasas, there is no statistical difference between exposed and unexposed children ${ }^{21}$. Given that affected sample areas in this revised sample have a much higher likelihood of individual level exposure to arsenic-polluted water wells, these findings corroborate our earlier result based on self-reported data for the full sample. These findings together with descriptive data presented in Table 6 and Appendix Table 3, confirm the reliability of our analysis based on self-reported data in section 4.1.

${ }^{21}$ Results are not reported but available from the authors upon request. 


\section{$5 \quad$ Conclusion}

Arsenic poisoning of drinking water today threatens millions of people in Bangladesh, West Bengal, Thailand and elsewhere in the USA, China and South America. While health consequences of such natural disaster are well-documented for adults, very little is known about the negative impact on children's developmental outcomes. To fill this gap in research, we have drawn upon survey data on secondary school children from arsenic affected and unaffected localities in Bangladesh, a country that has experienced the most severe form of arsenic poising to date. We find a negative relationship between arsenic contamination of drinking water wells at home, and test scores among children currently enrolled in school, net of school level exposure and socio-economic background of the child. This relationship is robust to our choice of dependent variables and controls for a variety of fixed-effects. The estimated effects range from -0.08 to -0.17 standard deviations for the primary mathematics test scores and for secondary mathematics, they range between -0.05 and -0.07 standard deviations.

To the extent that health is an important input in educational production and children in arsenic-affected households have suffered in terms of health owing to arsenicosis, our finding is unsurprising. However, there are a number of other potential explanations for the observed correlation between arsenic exposure and test scores. In this study, we have not exhaustively tested for all such possibilities. Nonetheless, we investigated the extent to which the potential effect of arsenicosis could hamper learning outcomes through social channels. It was found that the effect is only specific to nonreligious schools which maintain a liberal disciplinary regime and dress code which in turn permits discrimination by fellow students on the basis of a child's physical attributes 
and health status. The lack of an effect of exposure to arsenic contaminated wells at home for Islamic religious school children, we speculate, is owing to restrictions on the dress code and on-campus socialization which altogether mitigate prospects for negative social effects of arsenicosis at school.

Our study differs from existing studies on arsenic contamination and children's well-being in Bangladesh in that we use large, nationally representative sample of older, school enrolled children. Therefore, we are able to exploit geographic variation in arsenic pollution of groundwater to study the effect on children. To the best of our knowledge, there is no study on arsenic exposure and children's well-being for any developing country that has used a large dataset of a cohort of secondary school going children. As such, our findings complement existing studies on the effect of arsenic contamination that use very small and purposive sample on very young children (e.g. Wasserman et al. 2004; 2007).

To conclude, to the extent our finding of the negative correlation between learning outcomes of children, and arsenic contamination of drinking water wells at home is causal, reducing exposure for this vulnerable group forms an important policy objective. To this end, there are a number of ways in which future research on arsenic exposure could inform policy relating to children's development. First, while arsenic poisoning of tubewells at school also serves as an additional route of exposure, for rampant school switching at the end of the primary cycle and lack of detailed data on pollution status of tubewells in primary school, we were unable to assess the actual impact of school level exposure - we have information on the pollution status of current (secondary) school and only control for past school level exposure in an indirect manner 
(i.e. controls for various past schooling inputs that may be correlated with pollution status of primary school tubewell). Knowledge of the relative effect of arsenic exposure at home and school is important as policy makers may seek to target all places where children potentially drink water and hence target schools as well households in reducing exposure. Future studies therefore should aim at collecting additional data on past exposure at all levels of schooling. Second, studies should also gather information on cognitive ability (e.g. Raven’s score), skin diseases, and direct anthropometric measure of health status to differentiate between various pathways through which arsenic affects children's development. Third, in addition to the contamination status of water sources, individual-level data on the extent of actual exposure should be collected, for instance, in terms of urine/blood samples from pupils. Fourth, in addition to achievement, the effect of arsenicosis should be investigated in the context of school participation/enrolment decisions. Lastly, some households may have switched to unsafe surface water in recent years thereby being exposed to microbiologically contaminated water following the nationwide arsenic testing campaign of the government. If so, future studies should involve randomized evaluations of arsenic decontamination of tubewells (or alternate provision of safe water) and the impact on learning outcomes. 


\section{References}

Ahmad, Sk. Akhtar, MH Salim Ullah Sayed, Shampa Barua, Manzurul Haque Khan, MH Faruquee, Abdul Jalil, Sk. Abdul Hadi and Humayun Kabir Khan (2001) “Arsenic in drinking water and pregnancy outcomes”, Environmental Health Perspectives, 109(6), 629-631.

Argos, M., T. Kaira, P. Rathouz, Y. Chen, B. Pierce, F. Parvez, T. Islam, A. Ahmed, M. Rakibuz-Zaman, R. Hasan, G. Sarwar, V. Slavkovich, A. van Geen, J. Graziano, and H. Ahsan (2010). Arsenic exposure from drinking water, and all-cause and chronic-disease mortalities in Bangladesh (HEALS): A prospective cohort study. The Lancet, 376(9737), 252 - 258.

Asadullah, M.N., Chaudhury, N. and Dar, A. (2007). Student achievement conditioned upon school selection: Religious and secular secondary school quality in Bangladesh. Economics of Education Review, 26 (6), 648-659.

Asadullah, M. N. and Chaudhury, N. (2009). Holy alliances: Public subsidies, Islamic high schools, and female schooling in Bangladesh. Education Economics, 17(3), 377-394.

ATSDR (2005). Toxicological Profile for Arsenic. Agency for toxic substances and disease registry (ATSDR), U.S. Department of Health and Human Services, Atlanta, GA.

BAMWSP (2005). A general analysis of the national tube well screening program data. Bangladesh Arsenic Mitigation Water Supply Project (BAMWSP), BACAMP Resource Centre, August 2005.

BGS/DPHE (2001). Arsenic contamination of groundwater in Bangladesh. Final Technical Report WC/00/19 (Kinniburgh DG, Smedley PL, eds). Keyworth, UK: British Geological 
Survey and Department of Public Health Engineering, Ministry of Local Government, Rural Development and Co-operatives, Government of Bangladesh.

Calderon, J., M. E. Navarro, et al. (2001). Exposure to arsenic and lead and neuropsychological development in Mexican children. Environmental Research, 85(2), 69-76.

Claudia, Hopenhayn, Ferreccio, Catterina, Browning, Steven R. Huang, Bin; Peralta, Cecilia; Gibb, Herman; Hertz-Picciotto, Irva (2003). Arsenic exposure from drinking water and birth weight. Epidemiology, 14, 593-602.

Chakraborti, Dipankar, Mrinal Kumar Sengupta, Mohammad Mahmudur Rahman, Sad Ahamed, Uttam Kumar Chowdhury, Md. Amir Hossain, Subhash Chandra Mukherjee, Shyamapada Pati, Kshitish Chandra Saha, R.N. Dutta, Quazi Quamruzzaman (2004). Groundwater arsenic contamination and its health effects in the Ganga-MeghnaBrahmaputra plain. Journal of Environmental Monitoring, 6(6), 74N-83N.

Corman, H. and Chaikind, Stephen (1998). The effect of low birthweight on the school performance and behavior of school-aged children. Economics of Education Review, 17(3), 307-316.

Ding, Weili \& Lehrer, Steven F. \& Rosenquist, J.Niels \& Audrain-McGovern, Janet (2009). The impact of poor health on academic performance: New evidence using genetic markers. Journal of Health Economics, 28(3), 578-597.

Ehrenstein, O. S. von, D. N. Guha Mazumder, M. Hira-Smith, N. Ghosh, Y. Yuan, G. Windham, A. Ghosh, R. Haque, S. Lahiri, D. Kalman, S. Das and A. H. Smith (2006). Pregnancy outcomes, infant mortality, and Arsenic in drinking water in West Bengal, India. American Journal of Epidemiology, 163(7), 662-669. 
Gomes-Neto, Joao Batista \& Hanushek, Eric A. \& Leite, Raimundo Helio \& Frota-Bezzera, Roberto Claudio (1997). Health and schooling: Evidence and policy implications for developing countries. Economics of Education Review, 16(3), 271-282.

Groot, W. and Maassen van den Brink, H. (2007). The health effects of education. Economics of Education Review, 26(2), 186-200.

Grossman, Michael (2008). The Relationship between health and schooling. Eastern Economic Journal, 34(3), 281-292.

Hadi, A. and Parveen R. (2004). Arsenicosis in Bangladesh: prevalence and socio-economic correlates. Public Health, 118(8), 559-64.

Hanchett, S (2006). Social aspects of the arsenic contamination of drinking water: a review of knowledge and practice in Bangladesh and West Bengal. In APSU Selected papers on the social aspects of arsenic and arsenic mitigation in Bangladesh, Arsenic Policy Support Unit, Dhaka, Bangladesh, 1-51.

Hamermesh, D. and Biddle, J, (1994). Beauty and the labor market. American Economic Review, 84(5), 1174-1194.

Hassan, M., Atkins, P. J. and Dunn, Christine E. (2005). Social implications of arsenic poisoning in Bangladesh. Social Science and Medicine, 61(10), 2201-2211.

Kaestner, Robert and Michael Grossman (2009). Effects of weight on children's educational achievement. Economics of Education Review, 28(6), 651-661.

Khan, M M H., Aklimunnessa, K, Kabir, M. and Mori, Mitsuru (2007). Determinants of drinking arsenic-contaminated tubewell water in Bangladesh. Health Policy and Planning, 22, 335-343. 
Li L, Ekström E-C, Goessler W, Lönnerdal B, Nermell B, Yunus M, et al. (2008). Nutritional status has marginal influence on the metabolism of inorganic arsenic in pregnant Bangladeshi women. Environ Health Perspective, 116, 315-321.

Marcotte, Dave E. and Steven W. Hemelt (2008). Unscheduled closings and student performance. Education Finance and Policy, 3(3), 316-38.

Marcotte, Dave E. and With Ben Hansen (2010). Time for school. Education Next, 10(1), 5259.

McArthur, J.M., Ravenscroft P., Safiullah S. and Thirlwall M.F. (2001). Arsenic in groundwater: testing pollution mechanisms for sedimentary aquifers in Bangladesh. Water Resources Research, 37(1), 109-117.

Madajewicz, M., Pfaff, A., van Geen, A., Graziano, J., Hussein, I., Momotaj, H., Sylvi, R. and Ahsan, H. (2007). Can information alone change behavior? Response to arsenic contamination of groundwater in Bangladesh. Journal of Development Economics, 84(2), $731-754$

Milton A.H., Smith W.P., Rahman B., Hasan Z., Kulsum Z., Kulsum U. (2005). Chronic arsenic exposure and adverse pregnancy outcomes in Bangladesh. Epidemiology, 16(1), 82-86.

Misra, K. (2006). Arsenic poisoning and remedial measures: A global scenario. Geological Society of America Annual Meeting, Philadelphia, 22-25 October.

Mitra, S. R., Guha D.N. Mazumder, Arindam Basu, Gladys Block, Reina Haque, Sambit Samanta, Nilima Ghosh, Meera M. Hira Smith, Ondine S. Von Ehrenstein, Allan H. Smith; (2004). Nutritional factors and susceptibility to arsenic-caused skin lesions in West Bengal, India. Environmental Health Perspectives, 112, 1104-1109. 
National Institute of Population Research and Training (NIPORT), Mitra and Associates, ORC Macro. 2005. Bangladesh Demographic and Health Survey 2004. Dhaka: NIPORT, Mitra and Associates; and Calverton, MD: ORC Macro.

National Institute of Population Research and Training (NIPORT), Mitra and Associates, ORC Macro. 2008. Bangladesh Demographic and Health Survey 2007. Dhaka: NIPORT, Mitra and Associates; and Calverton, MD: ORC Macro.

Perri, Timothy J. (1984). Health status and schooling decisions of young men. Economics of Education Review, 3(3), 207-213.

Smith, A.H., Marshall, G., Yuan, Y., Ferreccio, C., Liaw, J., Ehrenstein, O., Steinmaus, C., Bates, M.N., and Selvin, S. (2006). Increased mortality from lung cancer and bronchiectasis in young adults following exposure to arsenic in utero and early childhood. Environmental Health Perspectives, 114(8), 1293-1296.

, Lingas, E.O. and Rahman, M. (2000). Contamination of drinking-water by arsenic in Bangladesh: a public health emergency. Bulletin of the World Health Organization, 78 (9), 1093-1103.

Shamim, I., and K. Salahuddin. 1994. Energy and water crisis in rural Bangladesh- Linkages with women's work and time. Dhaka: Women for Women.

Sultana, F. (2006). Gender concerns in arsenic mitigation in Bangladesh: trends and challenges. In APSU Selected papers on the social aspects of arsenic and arsenic mitigation in Bangladesh, Arsenic Policy Support Unit, Dhaka, Bangladesh: 53-84.

Sun, Ang and Yao, Yang (2010). Health shocks and children's school attainments in rural China. Economics of Education Review, 29(3), 375-382. 
Tella, R.D. and MacCulloch, R. (2006). Some uses of happiness data in economics. Journal of Economic Perspectives, 20(1), 25-46.

Tokar, E. J., Qu, W. and Waalkesm, M. P. (2011). Arsenic, stem cells, and the developmental basis of adult cancer. Toxicological Science, 120, S192-S203.

van Geen, A., Ahmed, K.M. and Madajewicz, M. (2005). The lethal water wells of Bangladesh. New York Times, July 30.

van Geen, A., Y. Zheng, R. Versteeg, M. Stute, A. Horneman, R. Dhar, M. Steckler, A. Gelman, C. Small, H. Ahsan, J. Graziano, I. Hussain, and K. Ahmed (2003). Spatial variability of arsenic in 6000 tube wells in a $25 \mathrm{~km} \mathrm{sq}$ area of Bangladesh. Water Resources Research, 39(5), 1.

Waalkes MP, Liu J, Diwan BA (2007). Transplacental arsenic carcinogenesis in mice. Toxicology Applied Pharmacology, 222, 271-280.

Wasserman, G. A., X. Liu, Faruque Parvez, Habibul Ahsan, Pam Factor-Litvak, Alexander van Geen, Vesna Slavkovich, Nancy J. LoIacono, Zhongqi Cheng, Iftikhar Hussain, Hassina Momotaj, and J. H. Graziano (2004). Water arsenic exposure and children's intellectual function in Araihazar, Bangladesh. Environmental Health Perspectives, 112(13), 1329-1333.

Wasserman, G. A., Xinhua Liu, Faruque Parvez, Habibul Ahsan, Pam Factor-Litvak, Jennie Kline, Alexander van Geen, Vesna Slavkovich, Nancy J. LoIacono, Diane Levy, Zhongqi Cheng, Joseph H. Graziano (2007). Water arsenic exposure and intellectual function in 6year-old children in Araihazar, Bangladesh. Environmental Health Perspectives, 115(2), 285-289. 
Zhao, Meng and Paul Glewwe (2010). What determines basic school attainment in developing countries? Evidence from rural China. Economics of Education Review, 29(3), 451-460.

Yu, W., C. Harvey, and C. Harvey (2003). Arsenic in groundwater in Bangladesh: A geostatistical and epidemiological framework for evaluating health effects and potential remedies. Water Resources Research 39(6), 1146. 
Appendix Table 1: Descriptive statistics, full sample

\section{Variable}

$\%$ of mathematics answer correct [secondary

standard]

$\%$ of mathematics answer correct [primary standard]

Happy [1=very unhappy; 4= very happy]

\section{Personal attributes}

Age

Age, squared

Female*

\section{Family background}

Home tubewell arsenic-poisoned*

No tubewell in the house*

Father primary educated*

Father secondary educated*

Father post-secondary educated*

Mother primary educated*

Mother secondary educated*

Mother post-secondary educated*

Household has a fan*

Household has a tv*

Household has a radio*

House is pucca*

House is semi-pucca*

Travel time to school from home (in minutes)

Schooling history

Attended pre-primary (maktab) school in childhood*

Class rank in grade 7

Attended private primary school*

Attended primary madrasa*

Attended primary NGO school*

Attended primary grade in this school*

Secondary school attributes

School tubewell arsenic-poisoned*

No tubewell in school*

Class size

Distance to the nearest secondary school

School expenditure (in logs)

Years to recognition

Received best school award from the government*

Fraction of grade 8 teachers being female

Fraction of grade 8 teachers being trained

Madrasa*

Single sex school*
Outcomes

Mean

SD

$\begin{array}{cc}0.38 & 0.20 \\ 0.78 & 0.27 \\ 3.07 & 0.86 \\ & \\ 13.23 & 0.95 \\ 175.82 & 29.76\end{array}$

$\begin{array}{ll}0.61 & 0.49\end{array}$

$\begin{array}{ll}0.12 & 0.32\end{array}$

$0.15 \quad 0.35$

$0.33 \quad 0.47$

$0.20 \quad 0.40$

$0.23-0.42$

$0.39 \quad 0.49$

$0.18-0.39$

$0.10-0.30$

$0.36 \quad 0.48$

$0.36-0.48$

$0.58 \quad 0.49$

$0.13-0.34$

$0.16 \quad 0.36$

$22.48 \quad 18.68$

$0.62 \quad 0.49$

$22.19 \quad 21.70$

$0.19-0.39$

$0.05-0.21$

$\begin{array}{ll}0.07 & 0.25\end{array}$

$0.03 \quad 0.18$

$\begin{array}{ll}0.30 & 0.46\end{array}$

$0.02 \quad 0.12$

$62.19 \quad 30.62$

$3.76-1.09$

$13.30 \quad 1.00$

$8.09-11.74$

$0.12-0.32$

$0.12 \quad 0.13$

$0.48-0.28$

0.20

$\begin{array}{ll}0.16 & 0.37\end{array}$

Note: (a) * indicates a dummy (1/0) variable. (b) Omitted class for parental education variable is "never went to school”. (c) Base category for house type and primary school type is "kacha (made of mud and bamboo)" and "government primary school" respectively. 
Appendix Table 2: Distribution of test and happiness score by self-reported arsenic exposure across schools and madrasas

\begin{tabular}{|c|c|c|c|c|c|c|}
\hline & \multicolumn{3}{|c|}{ Non-religious school } & \multicolumn{2}{|c|}{ Islamic school } & \\
\hline & $\begin{array}{l}\begin{array}{c}\text { Arsenic } \\
\text { (yes=1) }\end{array} \\
\end{array}$ & $\begin{array}{c}\text { Arsenic } \\
(\text { yes }=0)\end{array}$ & & $\begin{array}{c}\begin{array}{c}\text { Arsenic } \\
(\text { yes }=1)\end{array} \\
\end{array}$ & $\begin{array}{c}\text { Arsenic } \\
(\text { yes }=0)\end{array}$ & \\
\hline $\begin{array}{l}\text { \% of mathematics answer } \\
\text { correct [secondary standard] }\end{array}$ & 0.36 & 0.38 & $*$ & 0.36 & 0.36 & - \\
\hline $\begin{array}{l}\% \text { of mathematics answer } \\
\text { correct [primary standard] }\end{array}$ & 0.72 & 0.77 & $*$ & .79 & .80 & - \\
\hline $\begin{array}{l}\text { Happy [1=very unhappy; } 4= \\
\text { very happy] }\end{array}$ & 2.97 & 3.07 & $*$ & 2.99 & 3.12 & $*$ \\
\hline $\mathbf{N}$ & 729 & 5455 & & 196 & 1300 & \\
\hline
\end{tabular}

Note: * indicates that difference in mean score between arsenic exposed and unexposed children is statistically significant (at $5 \%$ level of significance).

Appendix Table 3: Distribution of children by self-reported arsenic exposure status and regional (based on official tests) exposure status

\begin{tabular}{|c|c|c|c|c|}
\hline & & & $\begin{array}{l}\text { Individual-level } \\
\text { (based on self-repo }\end{array}$ & $\begin{array}{l}\text { posure } \\
\text { ted data) }\end{array}$ \\
\hline & & $\begin{array}{c}\text { \# of } \\
\text { sample } \\
\text { Unions }\end{array}$ & $\begin{array}{c}\text { \# of sample } \\
\text { children reporting } \\
\text { home tubewell to be } \\
\text { arsenic } \\
\text { contaminated } \\
\end{array}$ & $\begin{array}{c}\text { Total \# of } \\
\text { sample } \\
\text { children } \\
\end{array}$ \\
\hline Arsenic & Sample Union affected & 37 & 648 & 4579 \\
\hline $\begin{array}{l}\text { of sample Union } \\
\text { (based on } \\
\text { formal test of } \\
\text { water wells }\end{array}$ & $\begin{array}{l}\text { Sample Union Arsenic free } \\
\text { but at least one } \\
\text { neighbouring Union } \\
\text { affected }\end{array}$ & 16 & 231 & 1928 \\
\hline BAMWSP) & $\begin{array}{l}\text { Sample Union } \\
\text { Arsenic free and }\end{array}$ & 7 & 46 & 1203 \\
\hline & & 60 & 925 & 7710 \\
\hline
\end{tabular}

Note: (a) Self-reported data on arsenic contamination is based on home tubewell being reported to be painted "red". (b) A tubewell is identified as officially contaminated if Arsenic concentration is found to be above 0.5 micro-gram per litre $(\mu \mathrm{g} / \mathrm{l})$. 
Appendix Figure 1: Map of sample Unions

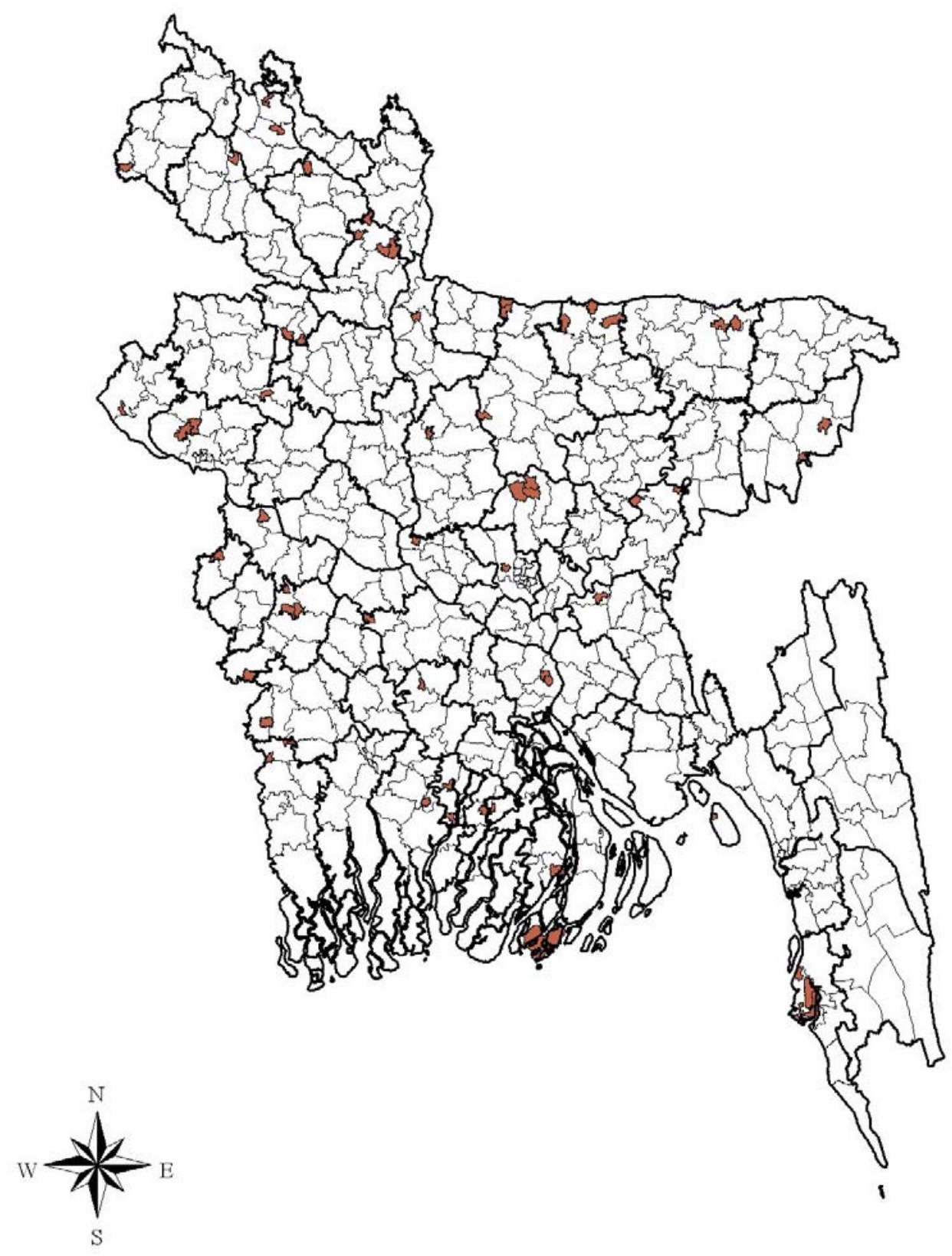


Appendix Figure 2: Arsenic contamination in sample Unions as per NAMIC data

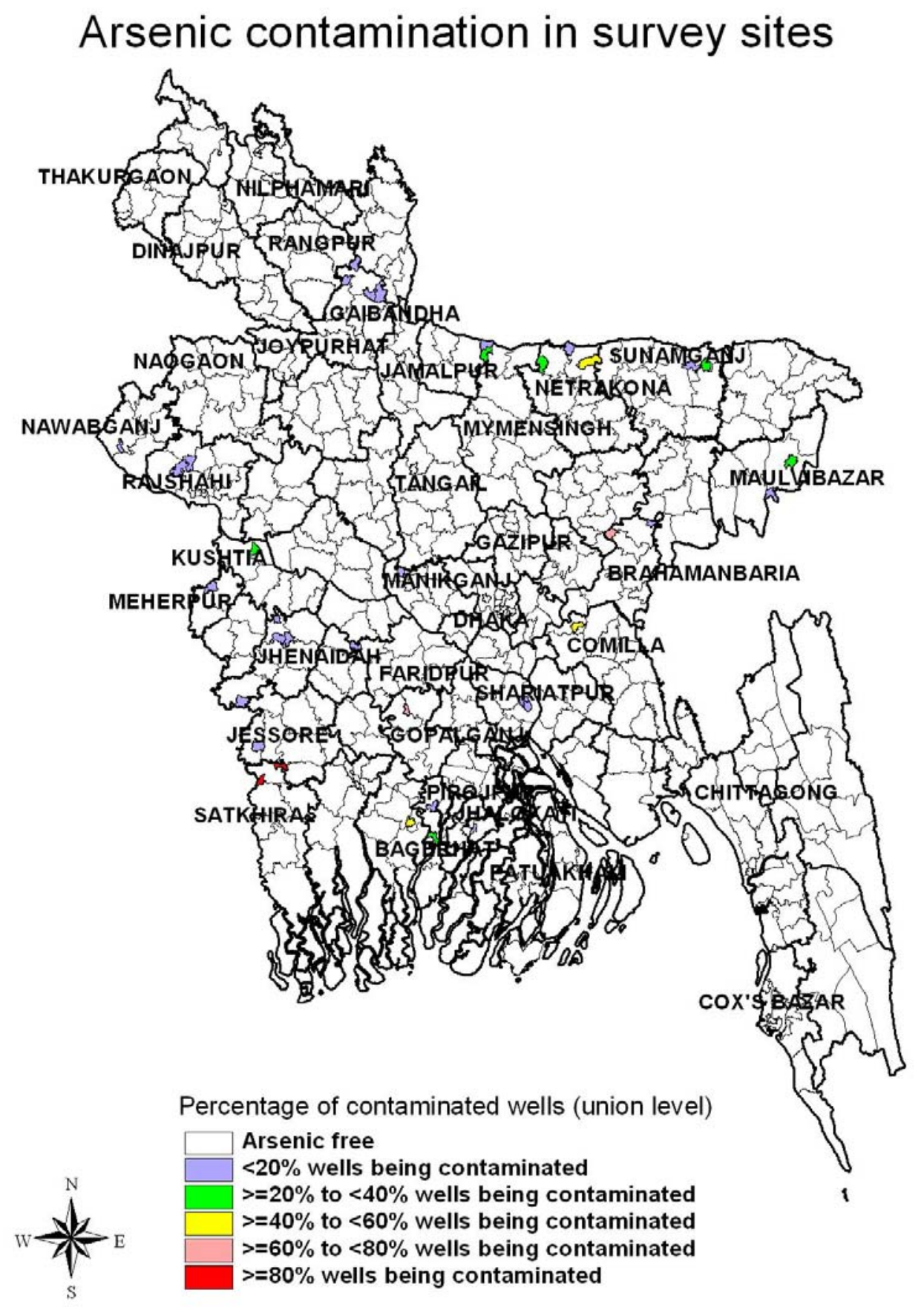

